\title{
Pembelajaran Berbasis ICT: Pelatihan Penggunaan Software GeoGebra Sebagai Strategi Efektif Peningkatan Profesionalitas Guru
}

\author{
ICT Based Learning: Training in Using GeoGebra Software as an Effective Strategy for \\ Increasing Teacher Professionalism
}

\author{
Elfi Rahmadhani* dan Septia Wahyuni \\ Jurusan Tarbiyah, Program Studi Tadris Matematika STAIN Gajah Putih Takengon, Email: \\ elfirahmadhani@stain-gp.ac.id
}

\begin{abstract}
Abstrak
Pengabdian kepada masyarakat ini bertujuan untuk menciptakan pembelajaran matematika berbasis ICT dengan mengenalkan dan menggunakan software Geogebra sebagai salah satu alternatif dalam meningkatkan profesionalitas guru. Kegiatan pengabdian ini bersifat pelatihan dan pendampingan dalam menggunakan software Geogebra. Metode yang digunakan adalah pemberian materi dan diskusi tentang software Geogebra dan cara menggunakannya, kemudian dilanjutkan dengan latihan/praktek penggunaan software tersebut dan diakhiri dengan presentasi hasil karya para guru berupa media pembelajaran matematika. Berdasarkan hasil evaluasi dan diskusi dengan para peserta diketahui bahwa para guru senang dengan adanya pelatihan penggunaan software Geogebra tersebut, karena membantu mereka dalam menyampaikan materi geometri yang pada umumnya merupakan materi yang sulit bagi siswa. Menurut mereka, penggunaan software ini dapat mengakomodir siswa yang tidak mempunyai kemampuan spatial thinking yang bagus, sehingga materi yang disampaikan dapat diterima oleh seluruh siswa.
\end{abstract}

Kata kunci: pembelajaran berbasis ICT, Geogebra

\begin{abstract}
This community service aims to create ICT-based mathematics learning by introducing and using GeoGebra software as an alternative in increasing teacher professionalism. This service activity are training and mentoring in using GeoGebra software. The method used are giving material and discussion about GeoGebra software and how to use it, then continued with the practice of using the software and ending with the presentation of the work of the teachers in the form of mathematics learning media. Based on the results of the evaluation and discussion with the participants it was known that the teachers were happy with the training in using the GeoGebra software because it helped them to convey geometric material which was generally difficult material for students. According to them, the use of this software can accommodate students who do not have good spatial thinking skills, so that the material delivered can be accepted by all students.
\end{abstract}

Keywords: ICT-based learning, GeoGebra

\section{PENDAHULUAN}

Di era revolusi industri 4.0 sekarang ini, sudah seharusnya seorang guru aktif menggunakan IT dalam menyampaikan konsep pelajaran, tidak hanya monoton dengan pembelajaran langsung saja. Kemajuan IT yang begitu pesat sekarang ini membawa dampak yang besar pula dalam pembelajaran matematika. Penggunaan perangkat lunak atau program aplikasi matematika telah memberikan warna tersendiri dalam pelajaran matematika. Dengan menggunakan aplikasi ini diharapkan konsep matematika yang bersifat 
abstrak dapat tersampaikan dengan baik melalui penggunaan aplikasi-aplikasi dalam matematika. Salah satu materi yang membutuhkan bentuk visual yang jelas agar konsep dapat tersampaikan dengan baik adalah Geometri. Geometri merupakan cabang matematika yang mempelajari titik, garis, bidang dan benda-benda ruang serta sifat-sifanya, ukuran-ukurannya dan hubungan satu sama lain (Moeharti, 1986). Sejalan dengan itu, Iswadji (2001) mengatakan bahwa geometri adalah ilmu pengetahuan yang tidak hanya mementingkan apa jawabnnya, tetapi juga bagaimana kita dapat sampai pada jawaban tersebut. Geometri mengembangkan kemampuan berfikir aksiomatik melalui penyusunan definisi dan pembuktian teorema/dalil dengan kalimat-kalimat yang tepat dan cermat sehingga mudah dipahami. Menurut Bird (2002:142) geometri merupakan bagian dari matematika yang membahas titik, garis bidang dan ruang serta berhubungan dengan konsep-konsep abstrak yang diberi simbol-simbol.

Objek di dalam geometri merupakan benda-benda yang sifatnya abstrak sehingga penguatan konsep bagi guru merupakan hal yang sangat penting. Kesalahan konsep yang diberikan oleh guru akan mengakibatkan konsep yang diterima siswa menjadi sumber kesalahan dan kesulitan dalam menyelesaikan pemecahan masalah geometri. Menurut Zimmermann dan Cunningham (1991) visualisasi dipandang sebagai salah satu cara yang tepat untuk membantu siswa memahami konsep-konsep matematika yang abstrak, yaitu dengan memanfaatkan media komputer. Hal ini sejalan dengan pendapat Sipos (2011), bahwa siswa sangat antusias pada pembelajaran geometri dengan menggunakan komputer. Namun kenyataannya, tidak semua guru menggunakan komputer sebagai salah satu media pengantar konsep dalam pembelajaran.

Beberapa guru SMP/MTs di Takengon masih menggunakan media papan tulis dalam menyampaikan materi geometri, terkadang mereka menggunakan Microsoft PowerPoint untuk membantu mereka menyampaikan materi dengan harapan siswa lebih tertarik dan lebih memahami konsep geometri yang diberikan. Namun hal ini tidaklah cukup, karena papan tulis dan Microsoft PowerPoint yang digunakan hanya mampu menampilkan bangun datar secara garis besar saja, ketika dihadapkan dengan koordinat kartesius, para guru mengalami kesulitan. Solusi yang ditawarkan oleh tim $\mathrm{PkM}$ adalah dengan mengadakan pelatihan penggunaan software Geogebra.

Geogebra merupakan software matematika dinamis yang mengintegrasikan aljabar, geometri dan kalkulus yang didesain untuk kebutuhan belajar tingkat sekolah menengah dan universitas (Preiner, 2008). Sebagai software matematika yang dinamis, software ini dapat dimanfaatkan untuk membuat konsep-konsep matematika menjadi dinamik. Geogebra dapat dimanfaatkan sebagai media pembelajaran matematika untuk mendemonstrasikan atau memvisualisasikan konsep-konsep matematika serta sebagai alat bantu untuk mengkonstruksi konsep-konsep matematis (Fazar, 2015).

Software Geogebra sangat membantu para guru dalam pembelajaran, karena mudah dioperasikan dan tidak menuntut harus mahir menggunakan komputer. Hal ini senada dengan pendapat Edward \& Jones (2006) bahwa software Geogebra cukup mudah dioperasikan sehingga bisa dijalankan oleh mereka yang tidak begitu menguasai komputer. Bahkan siswapun bisa menggunakan software ini. Karena Geogebra dikembangkan oleh Markus Hohenwarter sebagai aplikasi yang tidak berbayar sehingga dapat digunakan oleh siapa saja termasuk siswa.

\section{SOLUSI/TEKNOLOGI}

Metode yang digunakan pada kegiatan pengabdian kepada masyarakat ini meliputi pemberian materi dan latihan penggunaan software Geogebra. Secara lebih rinci, jenis 
kegiatan yang dilakukan selama pengabdian ini adalah:

1. Pemberian materi dan diskusi. Kegiatan ini merupakan kegiatan awal yang dilakukan pada pelatihan. Dimulai dengan penyampaian secara umum mengenai pentingnya pemanfaatan teknologi ICT dalam pembelajaran matematika, dan peranan media berbasis teknologi (software Geogebra) dalam pembelajaran matematika. Pada tahap ini peserta diberikan modul penggunaan software Geogebra yang telah dikembangkan oleh tim PkM, dan dilakukan penginstalan software Geogebra pada semua laptop peserta. Setelah dilakukan instalasi, maka diberikan penjelasan tentang tampilan dasar dan tools yang ada pada software Geogebra.

2. Praktek atau latihan penggunaan software Geogebra. Kegiatan ini merupakan tahap kedua pada PkM yang dilakukan. Pada tahap ini para peserta dibagi menjadi beberapa kelompok untuk melakukan praktek penggunaan software Geogebra. Diberikan beberapa latihan dasar untuk membantu pemahaman peserta dengan software yang digunakan.

3. Presentasi. Kegiatan ini merupakan tahap terakhir dari kegiatan pelatihan. Pada tahap ini para peserta diminta untuk mempresentasikan beberapa karya mereka terkait dengan penggunaan software Geogebra. Dengan presentasi yang dilakukan, maka peserta dan tim PkM dapat melakukan evaluasi sejauh mana pemahaman para peserta dengan materi yang telah diberikan. Setelah semua kegiatan terlaksana, maka sebelum kegiatan pelatihan ditutup, para peserta diberikan angket untuk mengevaluasi kegiatan PkM yang telah dilakukan. Hal ini dilakukan untuk melihat ketercapaian tujuan kegiatan pengabdian kepada masyarakat yang dilakukan.

\section{HASIL DAN DISKUSI}

Kegiatan pengabdian kepada masyarakat $(\mathrm{PkM})$ ini dilakukan pada hari Sabtu s/d Minggu pada tanggal 4 s/d 5 Februari 2017 dengan jumlah peserta adalah 25 orang guru-guru SMP/MTs di Takengon. Kegiatan pengabdian ini terdiri dari tiga tahap yaitu pemaparan materi dan diskusi, praktek atau latihan dan presentasi.

Pada hari pertama kegiatan PkM, tim $\mathrm{PkM}$ menyajikan materi pelatihan berupa pemaparan mengenai pentingnya penggunaan IT/ICT untuk membantu guru dalam menyampaikan materi pelajaran serta memberikan penjelasan mengenai software Geogebra dan tools yang ada dalam software tersebut. Para peserta pada hari pertama diberikan modul yang berisikan sekilas materi tentang software Geogebra dan bagaimana cara mengoperasikan software tersebut. Modul ini diberikan untuk mempermudah peserta pelatihan dalam menggunakan software Geogebra. Pada hari pertama ini, software Geogebra diinstal ke setiap laptop peserta, sehingga peserta dapat berlatih langsung bagaimana cara menggunakan software tersebut. Setelah tim PkM memaparkan materi, para peserta dapat bertanya seputar software yang digunakan.

Pada sesi tanya jawab, terlihat peserta sangat antusias mengikuti kegiatan pelatihan ini. Terlihat dari banyaknya pertanyaan yang dilontarkan oleh peserta terkait dengan penggunaan software Geogebra ini. Karena menurut pendapat mereka, kegiatan seperti ini jarang mereka dapatkan sehingga pelatihan seperti inilah yang mereka tunggu selama ini untuk meningkatkan kemampuan dan pengetahuan mereka.

Pada hari kedua kegiatan pelatihan, dilakukan praktek atau latihan cara menggunakan software Geogebra, sehingga para peserta dapat menghasilkan suatu media pembelajaran berbasis ICT dalam 
membantu mereka menyampaikan materi Geometri kepada siswa. Pada tahap ini, para peserta dibagi menjadi beberapa kelompok yang terdiri dari 3-4 orang. Masing-masing kelompok memilih sendiri materi yang akan mereka sajikan dengan menggunakan software Geogebra. Setelah peserta menyelesaikan media mereka, maka saatnya untuk mempresentasikan media atau hasil karya mereka untuk melihat seberapa paham mereka menggunakan software tersebut. Media yang telah mereka buat akan diperbaiki dan disempurnakan, sehingga setelah kegiatan pelatihan ini berakhir para peserta mempunyai suatu media yang dapat mereka gunakan dalam pelajaran matematika.

Sebelum pelatihan berakhir, disesi terakhir para peserta diberikan suatu angket untuk melihat bagaimana respon mereka dengan kegiatan pelatihan yang telah mereka ikuti. Berdasarkan hasil evaluasi tersebut diketahui bahwa para peserta mendukung kegiatan pelatihan ini, malahan mereka menginginkan kegiatan seperti ini dapat terus berlangsung untuk meningkatkan kemampuan dan pengetahuan mereka sehingga menjadi guru yang professional dan mampu mengikuti tuntutan zaman.

\section{KESIMPULAN}

Berdasarkan hasil evaluasi terhadap kegiatan pelatihan yang telah dilaksanakan dapat disimpulkan bahwa peserta $\mathrm{PkM}$ sangat mendukung adanya kegiatankegiatan pelatihan seperti ini dan diharapkan akan ada lagi kegiatan pelatihan serupa untuk meningkatkan pengetahuan dan kemampuan para guru agar mereka professional di bidangnya. Para peserta juga terlihat sangat antusias dengan kegiatan yang dilakukan, terlihat dari diskusi yang aktif dan kehadiran peserta yang total selama dua hari kegiatan pelatihan berlangsung.

\section{UCAPAN TERIMA KASIH}

Ucapan terima kasih diberikan kepada guru-guru SMP/MTs Takengon yang telah berpartisipasi dengan aktif dalam kegiatan pelatihan penggunaan software Geogebra untuk meningkatkan profesionalitas para guru.

\section{PUSTAKA}

Bird, J. (2002). Matematika Dasar Teori dan Aplikasi. Jakarta: Erlangga

Edward, J.A \& Jones, K. (2006). Linking Geometry and Algebra with GeoGebra. Mathematics Teaching, Incorporating MicroMath 194. Hal. 28-30

Fazar, I. (2015). Pemanfaatan Aplikasi Geogebra Dalam Kegiatan Pembelajaran Matematika di Sekolah Menengah Atas. Palembang Iswadji, Djoko. (2001). Geometri Ruang. Yogyakarta: Universitas Negeri Yogyakarta Juruasan Pendidikan matematika

Moeharti. (1986). Sistem-Sistem Geometri. Jakarta: Karunia Universitas Terbuka

Preiner, J. (2008). Introducing Dynamic Mathematics Software to Mathematics Teachers: the Case of GeoGebra. Disertasi. Mathematics Education, Faculty of Natural Science, University of Salzburg

Sipos, E.R. (2011). Teaching Geometry. Disertasi. Bolyai Institute, University of Szeged. http://www.math.uszeged.hu/phd/dreposit/phdtheses/rip co-sipos-elvira a2.pdf.

Zimmermann, W \& Cunningham, S. (1991). Editors' Introduction: What is Mathematical Visualization?. Dalam Zimmermann, W dan Cunningham, S. Visualization in Teaching and Learning Mathematics. Hal. 1-8. Washington DC: Mathematical Association of America 